\title{
Pregnancy with thalassemia: challenges and outcomes
}

\section{Vidhika Berwal, Amit Kyal*, Dorothy Dessa, Joyita Bhowmik, Payel Mondal, Partha Mukhopadhyay}

Department of Obstetrics and Gynecology, Medical College Kolkata, Kolkata, West Bengal, India

\author{
Received: 15 February 2018 \\ Accepted: 09 March 2018 \\ *Correspondence: \\ Dr. Amit Kyal, \\ E-mail: amitkyal@yahoo.com
}

Copyright: $($ ) the author(s), publisher and licensee Medip Academy. This is an open-access article distributed under the terms of the Creative Commons Attribution Non-Commercial License, which permits unrestricted non-commercial use, distribution, and reproduction in any medium, provided the original work is properly cited.

\begin{abstract}
Background: Thalassemia syndromes are autosomal recessive disorders and the most commonly inherited haemoglobinopathies in the world. $\mathrm{HbE} \beta$ is the most common type of thalassemia in eastern India. The objectives of the study include maternal outcome and complications like anemia, hypertensive disorders, gestational diabetes mellitus and also to study the neonatal outcome in terms of low birth weight, prematurity and other complications.

Methods: A prospective longitudinal study carried out over a period of one year from July 2016 to June 2017 in Medical College, Kolkata. Fifty antenatal thalassemic mothers over 20 weeks of gestation during study period were enrolled in after institutional ethical clearance and consent from study subjects. All necessary investigations (complete haemogram, reticulocyte counts, Ultrasounds etc.) were done followed by statistical analysis.

Results: Out of total 50 diagnosed thalassemic patients, maximum were HbE Beta Thal i.e. 54.0\%. The mean level of iron in these women varied from $95.70 \pm 17.16 \mu \mathrm{g} / \mathrm{dl}$ to $99.46 \pm 18.19 \mu \mathrm{g} / \mathrm{dl}$ at the time of delivery and ferritin varied from $185.40 \pm 49.26 \mu \mathrm{g} / \mathrm{L}$ vs $194.13 \pm 48.80 \mu \mathrm{g} / \mathrm{L}$. The mean blood transfusion done was 6.84 Units. Incidence of maternal complications were variable, PIH was found to be $26 \%$ whereas it was just $8 \%$ for GDM. The mean gestational age at delivery (Mean \pm SD) was 36.30 \pm 2.08 weeks. NICU admission was high (50\%).

Conclusions: Pregnancy with thalassemia is considered high risk, continuous pre-conceptional, antenatal and postpartum assessment should be done for favorable outcomes.
\end{abstract}

Keywords: Blood transfusion, High risk, Thalassemia

\section{INTRODUCTION}

More than 70000 babies are born with thalassemia worldwide each year and there are 100 million individuals who are asymptomatic thalassemia carriers. ${ }^{1}$ Thalassemia syndromes are autosomal recessive disorders and the most commonly inherited haemoglobinopathies in the world. The pathophysiology of thalassemia syndromes is characterised by extravascular haemolysis due to the release into the peripheral circulation of damaged red blood cells and erythroid precursors because of a high degree of ineffective erythropoiesis. ${ }^{2}$ Thalassemia is of two types: $\alpha$ - thalassemia and $\beta$ - thalassemia. $\mathrm{HbE}$ beta thalassemia is a double heterozygous state of $\mathrm{HbE}$ and beta thalassemia. It is the most common type of thalassemia in eastern India. Antenatal counselling is required for all antenatal mothers with thalassemia. Guidelines should be set up for the proper management of such a case during both antenatal and postnatal period. This study is conducted to document the management given to mothers with thalassemia in a tertiary care hospital and the outcome in each case.

The objectives were to study maternal outcome and complications like anemia, hypertensive disorders, 
gestational diabetes mellitus and also to study the neonatal outcome in terms of low birth weight, prematurity.

\section{METHODS}

It was a prospective longitudinal study which was carried out in the Department of Obstetrics and Gynaecology, Eden Hospital, Medical College, Kolkata over a period of one year between July 2016 to June 2017. Fifty antenatal thalassaemic mothers during study period were enrolled in after institutional ethical clearance and consent from study subjects.

Patients who were more than 20 weeks of gestation and conforming to inclusion and exclusion criteria were taken.

\section{Inclusion criteria}

age between 15-45 yrs who were diagnosed cases.

\section{Exclusion criteria}

Less than 20 weeks gestation, hemoglobinopathies and anemia due to other causes, medical disorders, multifetal pregnancy, malpresentation and congenital malformations.

After recruitment into the study, informed consent, a clinical examination was undertaken followed by appropriate laboratory investigations and ultrasounds. Patients with any complications (maternal/fetal) were admitted and treated. All patients recruited in the study were followed up till delivery and postpartum period up to 7 days.

The necessary information was recorded in the predesigned proforma. Laboratory investigations like Complete Hemogram, LFT, serum ferritin, reticulocyte count, Ultrasounds and ECG if required were done. Descriptive statistical analyses were performed to calculate the means with corresponding standard deviations. Test of proportion was used to find the Standard Normal Deviate $(Z)$ to compare the difference proportions and Chi-square test was performed to find the associations. In the cases where one of the cell frequencies were less than 5 corrected Chi-square was used to find the association between variables. t-test was used to compare the means. $\mathrm{P}$ value $<0.05$ was taken to be statistically significant.

\section{RESULTS}

Out of total 50 patients who participated, the mean age (mean \pm SD) of the patients was $23.84 \pm 3.68$ years with range 18-32 years and the median age was 24 years. The obstetric history of the patients which showed maximum patients were primigravida.
Table 1: Distribution of HPLC report of the patients.

\begin{tabular}{|lll|}
\hline HPLC report & Number & Percentage \\
\hline Homozygus Beta thal & 6 & 12.0 \\
\hline Beta thal trait & 17 & 34.0 \\
\hline HbE Beta thal & 27 & 54.0 \\
\hline Total & 50 & 100.0 \\
\hline
\end{tabular}

HPLC reports of all patients showed that proportion of patients with of $\mathrm{HbE}$ Beta Thalassemia was significantly higher $(54.0 \%)(\mathrm{Z}=3.53 ; \mathrm{p}<0.001)$.

Table 2: HPLC report of the husbands.

\begin{tabular}{|lll|}
\hline HIPLC report (husbands) & Number & Percentage \\
\hline Beta thal trait & 10 & 20.0 \\
\hline Normal & 40 & 80.0 \\
\hline Total & 50 & 100.0 \\
\hline
\end{tabular}

Most of the HPLC report of the husband of the patients were normal. $(Z=8.48 ; p<0.0001)$. Twenty percentage of them had Beta Thalassemia Trait.

Table 3: Level of $\mathrm{Hb}$, iron and ferritin at admission and at the time of delivery of the patients.

\begin{tabular}{|c|c|c|}
\hline & $\begin{array}{l}\text { At admission } \\
(n=50)\end{array}$ & $\begin{array}{l}\text { At the time of } \\
\text { delivery }(n=50)\end{array}$ \\
\hline \multicolumn{3}{|c|}{ Level of $\mathrm{Hb}(\mathrm{gm \%})$} \\
\hline Mean \pm SD & $8.40 \pm 1.04$ & $9.02 \pm 0.92$ \\
\hline Median & 8.65 & 9.00 \\
\hline Range & $5-11$ & $7-12$ \\
\hline \multicolumn{3}{|c|}{ Level of ferritin $(\mu \mathrm{g} / \mathrm{L})$} \\
\hline Mean \pm SD & $185.40 \pm 49.26$ & $194.13 \pm 48.80$ \\
\hline Median & 160.00 & 168.00 \\
\hline Range & $144-320$ & $150-318$ \\
\hline \multicolumn{3}{|c|}{ Level of iron $(\mu \mathrm{g} / \mathrm{dl})$} \\
\hline Mean \pm SD & $95.70 \pm 17.16$ & $99.46 \pm 18.19$ \\
\hline Median & 92.00 & 95.00 \\
\hline Range & $56-150$ & $60-156$ \\
\hline
\end{tabular}

Student t-test showed that the mean level of $\mathrm{Hb}$ at the time of delivery was significantly higher than that of at the time of admission $\left(\mathrm{t}_{98}=45.54 ; \mathrm{p}<0.0001\right)$.

Table 4: Incidence of maternal complications.

\begin{tabular}{|lll|}
\hline Complications & $\begin{array}{l}\text { Number } \\
(\mathrm{n}=50)\end{array}$ & $\%$ \\
\hline PIH & 13 & 26 \\
\hline GDM & 4 & 8 \\
\hline IUGR & 8 & 16 \\
\hline
\end{tabular}

Though the mean level of ferritin at the time of delivery was higher than that of at the time of admission t-test showed that there was no significant difference between two means ( $\left.\mathrm{t}_{98}=0.87 ; \mathrm{p}=0.38\right)$. The mean level of iron in these women varied from $95.70 \pm 17.16 \mu \mathrm{g} / \mathrm{dl}$ to $99.46 \pm 18.19 \mu \mathrm{g} / \mathrm{dl}$ in these women which was higher than 
normal pregnant women in second half of pregnancy 65$75 \mu \mathrm{g} / \mathrm{dl}$. Mean blood transfusion in pregnancy was $6.84 \pm 5.39$. The minimum was 1 and the maximum was 15 times

Twenty-six percentage of the patients developed hypertensive disorders during antenatal period. It included less severe form i.e. gestational hypertension to more severe forms i.e. pre-eclampsia and eclampsia. Only $8 \%$ were found to be complicated by GDM. The mean gestational age at delivery (Mean \pm SD) of the patients was $36.30 \pm 2.08$ weeks with range 30-39 weeks and the median was 37 weeks. $46.0 \%$ of the patients had pre term labour. $14.0 \%$ of the patients were underwent LSCS which was significantly lower than vaginal delivery. Indications included foetal distress, previous caeserian section in labor, CPD in labor etc. Six percentage of the patients had PPH. Only 1 of the 3 incidents occurred after LSCS, rest 2 followed vaginal deliveries. All of them were managed by medical management.

Table 5: Distribution of birth weight.

\begin{tabular}{|lll|}
\hline Birth weight $(\mathrm{kg})$ & Number & Percentage \\
\hline $1.5-2.0$ & 12 & 24.0 \\
\hline $2.1-2.5$ & 12 & 24.0 \\
\hline $2.6-3.0$ & 21 & 42.0 \\
\hline $3.1-3.5$ & 5 & 10.0 \\
\hline Total & 50 & 100.0 \\
\hline
\end{tabular}

The mean neonatal birth weight $($ Mean \pm SD) of the patients was $2.48 \pm 0.44 \mathrm{~kg}$ with range $1.70-3.50 \mathrm{~kg}$ and the median was $2.60 \mathrm{~kg}$. $42.0 \%$ of the neonates has birth weight between $2.6-3.0 \mathrm{~kg}$ which was significantly higher $(Z=2.70 ; p<0.05) .48 \%$ contributed to low birth weight.

Table 6: Incidence of neonatal complications.

\begin{tabular}{|lll|}
\hline Complications & Numbers $(\mathbf{n}=50)$ & Percentage \\
\hline NICU admission & 25 & 50 \\
\hline Sepsis & 3 & 6 \\
\hline Jaundice & 23 & 46 \\
\hline
\end{tabular}

Table 6 showed $46 \%$ of the neonates developed jaundice whereas only $6 \%$ developed sepsis.

\section{DISCUSSION}

Age distribution of patients in present study shows that Proportion of patients in the age group of 20-24 years $(56.0 \%)$ were significantly higher than other age group. However, Rafael et al observed that The mean age of pregnancy was higher in thalassemia intermedia which was(30.7 \pm 5.6 years) in a study conducted in Italy in various centres. ${ }^{3}$ Proportion of primigravida patients were significantly higher (34\%) than other parity groups.

HPLC report of all patients as shown in table 3, shows that the frequency of $\mathrm{HbE}$ Beta Thalassemia was highest $(54.0 \%)$ followed by $\beta$ thalassemia trait patients who accounted for $34 \%$. The findings in the present study were similar with Samrat Chakrabarty et al who found out of 31 cases, $38 \%$ were E $\beta$ thalassemia, 9 cases $\mathrm{HbE}$ trait, $29 \%$ were $\beta$ thalassemia trait and $3.2 \%$ was sickle $\beta+$ thalassemia. $^{4}$

Fifty patients enrolled in present study, HPLC of all of their husbands was done, analysis of which showed that $10(20 \%)$ were $\beta$ thalassemia trait. All the couples who participated received proper genetic counselling in terms of risks of inheritance to the baby but any kind of invasive procedures like amniocentesis or CVS could not be done as the patients were more than 20 weeks of gestation. This data did not match with that of Asha Baxi et al in which only one couple (3.5\%) was found to have $\beta$ thalassemia trait. It was quiet low as compared to the present study. CVS was done to exclude thalassemia major in this study. 5

The mean $\mathrm{Hb}$ at admission was $8.40 \pm 1.04 \mathrm{gm} \%$ and at the time of delivery was $9.02 \pm 0.92 \mathrm{gm} \%$. The findings partially correlated with Raffaella Origa et al who observed. The mean hemoglobin concentration prior to transfusion was $7.6 \pm 0.6 \mathrm{gm} / \mathrm{dL}$, while that after delivery was $9.3 \pm 0.6 \mathrm{gm} / \mathrm{dL}$

Iron stores in the body exist primarily in the form of ferritin. The concentration of this plasma (or serum) ferritin is positively correlated with the size of the total body iron stores in the absence of inflammation. The mean ferritin level in present study was found to be $185.40 \pm 49.26 \mu \mathrm{g} / \mathrm{L}$ at the time of booking and $194.13 \pm 48.80 \mu \mathrm{g} / \mathrm{L}$ at the time of delivery. The results of present study were not consistent with Anwar et al in which the average ferritin level before pregnancy was $885.2 \pm 658.9 \mu \mathrm{g} / \mathrm{L}$ vs. $1232.8 \pm 902.9 \mu \mathrm{g} / \mathrm{L}$ after pregnancy. ${ }^{6}$ Daskalakis GJ et al found very high values as compared to present study which were 1,480 to $9,160 \mu \mathrm{g} / 1$. $^{7}$

The mean blood transfusion done to the patient was 6.84 units during antenatal period. Maximum number of transfusions done were 15 and minimum number of transfusion done to a patient was only 1. Blood transfusion in the current study was done if $\mathrm{Hb} \leq 7 \mathrm{gm} \%$ or if patients were symptomatic.

All the patients of thalassemia major and $\mathrm{HbE} \beta$ thalassemia required blood transfusion, whereas only $50 \%$ patients of thal trait received blood transfusion. Michalas et al conducted a study in which target $\mathrm{Hb}$ was $10 \mathrm{gm} \%$, this target had been achieved before pregnancy, with regular blood transfusions of a mean of two units of washed packed red cells which changed to every three to five weeks (mean transfusion interval 25 days) which was very high in comparison to our observation. ${ }^{7}$

Incidence of PIH is $26 \%$ in present study. The findings of the present study did not coincide with Mehran et al who did a comparative study between $510 \beta$-thalassemia minor subjects and 512 healthy controls. There was no 
significant difference regarding preeclampsia $(\mathrm{p}=0.116)$ between two study groups. ${ }^{6}$ Eight percentage patients developed gestational diabetes mellitus. Mehran et al on the other hand concluded otherwise, according to them there was no relation between GDM and thalassemia. ${ }^{6}$ Study shows $14 \%$ patients underwent caesarean section and $86 \%$ were delivered vaginally. Usta et al found the contrary Cesarean delivery was performed in $42.9 \%$ of cases. $^{8} 46 \%$ had preterm birth in present study. On the contrary Shahla et al found very low incidence of preterm birth. All babies were normal; 45 cases were mature and only 5 were preterm. ${ }^{9}$

The mean neonatal birth weight of the patients was $2.48 \pm 0.44 \mathrm{~kg}$ with range $1.70-3.50 \mathrm{~kg}$ and the median was $2.60 \mathrm{~kg}$. Of total babies, $48 \%$ were low birth weight. The case series conducted at Maharaj Nakorn Chiang Mai Hospital indicates that, in spite of an attempt to keep hemoglobin levels above $7.0 \mathrm{gm} / \mathrm{dl}$, pregnancy with thalassaemia is likely to be associated with an increased rate of low birth weight which was comparable to present study $(44.1 \%) .{ }^{10}$

\section{CONCLUSION}

Pregnancy with thalassemia is considered high risk for both mothers and foetus. Favourable outcomes can be obtained by continuous pre-conceptional, antenatal and postpartum assessment. Pre-marriage counselling and prenatal screening of partners of thalassaemic mothers should be done to decrease the thalassaemic burden of the society. Prenatal diagnostic tests like CVS/NIPT should be done when both husband and wife are affected by thalassemia to decrease the number of babies born with thalassemia. Advances in chelation therapy along with regular transfusion have introduced a new era for thalassaemic population.

\section{Funding: No funding sources}

Conflict of interest: None declared

Ethical approval: The study was approved by the Institutional Ethics Committee

\section{REFERENCES}

1. Weatherall DJ. The definition and epidemiology of non-transfusion dependent thalassemia. Blood Rev. 2012;26:S3-6.
2. Shinar E, Rachmilewitz EA. Oxidative denaturation of red blood cells in thalassemia. Semin Hematol. 1990;27:70-82

3. Origa R, Piga A, Quarta G, Forni G, Longo F, Melpignano A, et al. Pregnancy and betathalassemia: an Italian multicentric experience. Haematol. 2010;95:376-81.

4. Chakrabarti S, Nayek H, Kanrar P, Mondal S. An observational study on thalassaemia in pregnancy and its effects with a view to find measures for reduction of its complications and improvement of maternal and perinatal outcome. J Evolut Med Dent Sci. 2014 Feb 3;3(5):1149-56.

5. Baxi A, Manila Kaushal, Kadhi P. Carrier screening for $\beta$-thalassemia in pregnant Indian women. Experience at a single centre in Madhya Pradesh. Indian J Hematol Blood Transfus. 2013;29(2):71-4.

6. Nassar AH, Naja M, Cesaretti C, Eprassi B, Cappellini MD, Taher A. Pregnancy outcome in patients with beta-thalassemia intermedia at two tertiary care centers, in Beirut and Milan. Haematol. 2008;93:1586-7.

7. Daskalakis GJ, Papageorgiou IS, Antsaklis AJ, Michalas SK. Pregnancy and homozygous beta thalassaemia major. $\mathrm{Br} \mathrm{J}$ Obstet Gynaecol. 1998;105:1028-32.

8. Traisrisilp K, Luewan S, Tongsong T. Pregnancy outcomes in women complicated by thalassemia syndrome at MaharajNakorn Chiang Mai Hospital. Arch Gynecol Obstet. 2009;279(5):685-9.

9. Ansari S, Azarkeivan A, Tabaroki A. Pregnancy in patients treated for beta thalassemia major in two centers (Ali Asghar Children's Hospital and Thalassemia Clinic): outcome for mothers and newborn infants. Pediatr Hematol Oncol. 2006;23:33-7.

10. Usta IM, Rechdan JB, Koussa S, Taher AT. Pregnancy in patients with $\beta$-thalassemia intermedia: outcome of mothers and newborns. Am $\mathbf{J}$ of Hematol. 2006;81(7):499-502.

Cite this article as: Berwal V, Kyal A, Dessa D, Bhowmik J, Mondal P, Mukhopadhyay P. Pregnancy with thalassemia: challenges and outcomes. Int $\mathbf{J}$ Reprod Contracept Obstet Gynecol 2018;7:1613-6. 